\title{
a-Smooth Muscle Actin and TLR9 Expression and Correlation in Breast Cancer
}

\author{
Aradhana Singh $^{1^{*}}$, Arghya Bandyopadhyay ${ }^{2}$, Narendranath Mukherjee ${ }^{3}$ and Anupam \\ Basu $^{1}$
}

${ }^{1}$ Department of Zoology, Molecular Biology and Human Genetics Laboratory, The University of Burdwan, India ${ }^{2}$ Assistant Professor, Department of Pathology, Burdwan Medical College and Hospital, India

${ }^{3}$ Department of Surgery, Burdwan Medical College and Hospital, India

*Corresponding author: Aradhana Singh, Department of Zoology, Molecular Biology and Human Genetics Laboratory, The University of Burdwan, Golapbag, Burdwan 713104, West Bengal, India, Tel: +91-9007-1627-29

\begin{abstract}
Introduction: Cancer microenvironment is a complex of different kinds of cells. Ligands of different Toll-like receptors has been used in clinical trials in past decade but the mixed outcome leads to further studies. Toll-like receptor 9 expression has been observed in different type of cancer. a-Smooth muscle actin ( $\alpha-S M A)$ is an indicator of myofibroblast. In previous studies, myofibroblasts was reported to induce angiogenesis and proliferation in cancer by providing growth factors and extracellular matrix. In the present study, we have tried to find out the effect of TLR9 expression on expression of $\alpha-S M A$ in breast cancer myofibroblasts.
\end{abstract}

Methods and material: Surgically resected tumor tissues from the breast cancer patient. To evaluate the expression of TLR9 and a-SMA in breast cancer, immunohistochemistry was carried out. Clinicopathological parameters were also studied to correlate the expression of TLR9 and $\alpha-S M A$. Correlation between TLR9 and $\alpha-S M A$ was also studied.

Result: In our study, TLR9 expression was found to be expressed in the ductal epithelial cells as well as in tumor associated fibroblast and mononuclear inflammatory cells. After correlating the expression of TLR9 with the a-SMA, we have found that expression of TLR9 in the stromal compartment was correlated with the a-SMA expression in stromal compartment.

Conclusion: TLR9 have appositive impact on expression of $\alpha$-SMA in stromal cells that might act as bad prognosis for the disease.

\section{Keywords}

Toll like receptor 9, a-SMA, Tumor microenvironment, Clinicopathological parameters, Immunohistochemistry

\section{Introduction}

Toll-like receptors are evolutionarily conserved pattern recognition receptor that recognizes microbial component as well as the several molecules generated by our body [1]. TLR-9 is a nucleic acid sensing TLR that recognizes unmethylated bacterial or viral CpG motif-containing DNA. Various human cancer cell lines as well as clinical tumors including breast, brain, lung, ovarian, prostate, kidney, gastric, hepatocellular carcinoma, cervical squamous cell carcinoma, glioma, colorectal cancer, and neuroblastoma has TLR9 expression. More recently, it has been reported that TLR9 expresses in stromal compartments of several tumors like esophagus, ovary, hepatocellular carcinoma [2-3]. The breast tumor microenvironment consists of the cancer-causing malignant epithelial cells, along with plasmacytoid-derived dendritic cells DCs (pDCs) and myofibroblasts in the stroma [4]. Myofibroblasts are present in most abundantly in the tumor stroma of breast, colon, melanoma, and various other solid tumors. Myofibroblasts can directly induce angiogenesis, tumor progression by stimulating tumor cell with the release of various growth factors and providing extracellular matrix [5]. These myofibroblasts possess a very distinct and peculiar morphology of large and plump cells; however, there several established markers that help in the molecular characterization of myofibroblasts. $\alpha$-Smooth muscle actin ( $\alpha$-SMA) has reported being one of the

Citation: Singh A, Bandyopadhyay A, Mukherjee N, Basu A (2020) $\alpha$-Smooth Muscle Actin and TLR9 Expression and Correlation in Breast Cancer. Int J Pathol Clin Res 6:108. doi.org/10.23937/24695807/1510108

Accepted: April 23, 2020: Published: April 25, 2020

Copyright: (C) 2020 Singh A, et al. This is an open-access article distributed under the terms of the Creative Commons Attribution License, which permits unrestricted use, distribution, and reproduction in any medium, provided the original author and source are credited. 
established markers for myofibroblasts [6]. In esophageal cancer, TLR9 expression in fibroblast is associated with a low rate of lymph node metastasis [7], while in renal cell carcinoma, mucoepidermoid salivary gland carcinoma, and pancreatic cancer, low tumor TLR9 protein expression is associated with poor survival [3]. TLR9 has been reported to be widely expressed by clinical breast tumor sample but the expression of TLR9 in the stromal compartment of the breast tumor and its clinicopathological significance, as well as its effect on stromal myofibroblast, has not been studied yet $[8,9]$.

In the present study, we have examined the expression of TLR9 in breast tumor samples. We have also investigated the expression of $\alpha$-SMA as a marker for stromal myofibroblast in the same cohort of the patients. Finally, we have tried to find out the correlation between the expression of TLR9 and $\alpha$-SMA in a breast tumor sample to understand the correlation of TLR9 on myofibroblast differentiation and cancer progression.

\section{Material and Methods}

\section{Patients and samples}

Subjects of 38 unilateral primary breast carcinomas undergone modified radical mastectomy from women at Burdwan Medical College and Hospital were included. The patients were diagnosed between 2016 and 2018. The histological subtype all the tumors were invasive carcinoma of no special type (NST). The number of positive axillary lymph nodes were evaluated by a qualified pathologist. They were graded according to Scarff Bloom Richardson's (SBR) grading system. Written consent was taken from all subjects included in the study. The study was approved by the institutional ethical committee.

\section{Immunohistochemistry (IHC)}

Tissue Sections of $4 \mu \mathrm{m}$ thickness were prepared from the paraffin-embedded tissue blocks. Tissue sections were deparaffinized in xylene and then rehydrated through a series of graded ethyl alcohol $(100 \%, 90 \%, 80 \%, 70 \%$, $50 \%$, and $30 \%)$. Tissues sections were treated in citrate buffer (pH-6.8) for $15 \mathrm{~min}$ to retrieve the antigen in a microwave. After cooling, tissues were washed in distilled water, followed by $1 \mathrm{X}$ PBS [pH 7.4]. The endogenous peroxide activity was blocked with $3 \% \mathrm{H}_{2} \mathrm{O}_{2}$ for $15 \mathrm{~min}$ utes. The samples were rinsed in 1 X PBS and then pre-incubated with a protein blocking solution (10\% Normal Goat Serum) for 1 hour in humidified chamber at $37^{\circ} \mathrm{C}$. Human TLR 9 primary antibody (Thermo Fischer Scientific, Catalog - PA5-20202), $\alpha$-SMA (Thermo Fischer Scientific, Catalog - 14-9060-80) and IgG (Catalog \# 31154) were incubated (1:100 dilution) at $4{ }^{\circ} \mathrm{C}$ overnight in a humid chamber. Slides were washed three times in $1 \mathrm{X}$ PBST and incubated with HRP conjugated anti-rabbit and anti-mouse secondary antibody (1:1000) for $30 \mathrm{~min}$ at room temperature. The peroxidase signal was visualized by treatment with a DAB substrate-chromogen system (Sigma, Cat No.-D3939) for 10 min. Finally, the sections were counter-stained with Harrish-hematoxylin. Experimental negative control slides were treated with antibody control to check any nonspecific bindings.

\section{Evaluation of IHC staining for the expression of TLR9 and $\alpha$-SMA}

TLR9 and $\alpha$-SMA immunostained slides were anonymized and blinded for the interpretation of the immunostaining score. For TLR9 as well as $\alpha$-SMA, a modified semi-quantitative intensity score ( $\mathrm{H}$ score) adapted from Measure, et al. (2016) [10] was used.

For, TLR9 expression in malignant epithelial cells, briefly; score 0 : Negative staining, score 1: Weak cytoplasmic staining, score 2: Moderate cytoplasmic staining, score 3: Strong cytoplasmic staining in most of the tumor cells, score 4: Strong cytoplasmic and sub-membranous staining in almost all tumor cells where $\mathrm{H}$ score 2-4 signifies overexpression and $\mathrm{H}$ score $0-1$ signifies under expression. A similar $\mathrm{H}$ score was developed for the expression of TLR9 in stromal cancer-associated fibroblast (CAFs) and mononuclear inflammatory cells (MICs) (score 0: Negative staining, score 1: Weak staining, score 2: Strong staining). TLR9 under-expression was defined with $\mathrm{H}$ score between 0 and 1 and TLR9 over-expression with an $\mathrm{H}$ score as 2.

A similar semi-quantitative intensity score ( $\mathrm{H}$ score) has been developed for the expression of $\alpha$-SMA in stromal myofibroblasts (score 0: Negative staining, score 1: Weak staining, score 2: Strong staining). TLR9 under-expression was defined with $\mathrm{H}$ score between 0 and 1 and TLR9 over-expression with an $\mathrm{H}$ score as 2 .

\section{Statistical analyses}

All statistical analyses were performed with Graph Pad Prism software package (Version 7.0). The correlation of TLR9 and $\alpha$-SMA protein expression and different clinicopathological parameters and comparison between the expressions of TLR9 and $\alpha$-SMA were determined using the chi-square test. In all tests, $\mathrm{p}$-value < 0.05 was considered statistically significant.

\section{Result}

\section{Expression of TLR9 in breast tumor sample}

IHC assay performed on tumor samples confirmed TLR9 protein localization in malignant epithelial cancer cells as well as in adjacent stromal cells, which are mainly comprised of stromal myofibroblast and mononuclear inflammatory cells (MICs) (Figure 1 and Figure 2). The clinicopathological analysis indicated that TLR9 expression in breast cancer has no significant association with age, histopathological stage, but there is a statistical correlation between lymph node metastasis and expression of TLR9 in malignant epithelial cells (Table 1). 

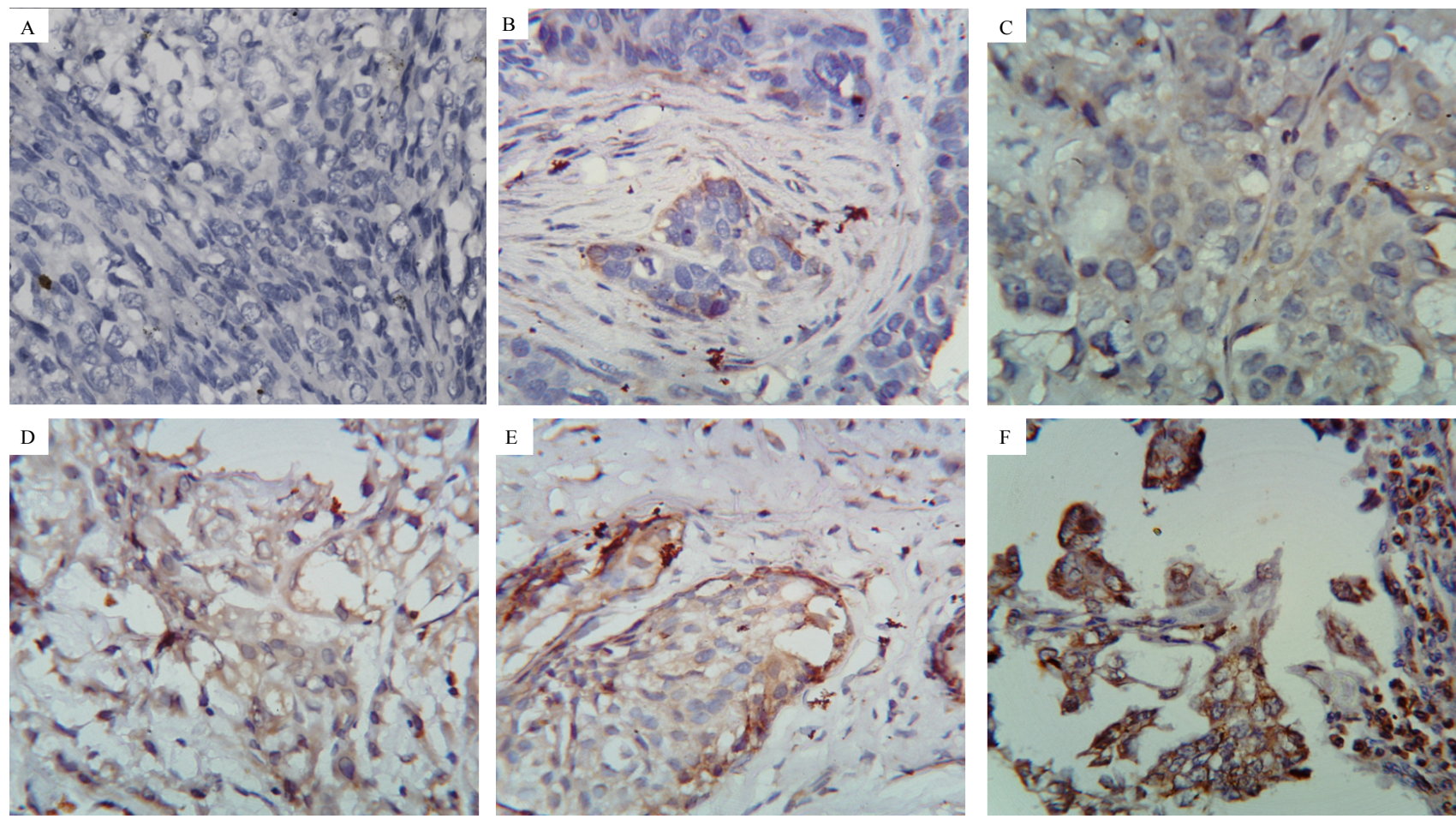

Figure 1: Immunohistochemical analysis for the expression of TLR9 in malignant epithelial cells of breast tumor tissue.

A) Experimental Negative Control 40X magnification; B to F: Stained with TLR9 primary antibody.

B) IHC score 0 at $40 \mathrm{X}$ magnification.

C) IHC score 1 at $40 X$ magnification.

D) IHC score 2 at $40 X$ magnification.

E) IHC score 3 at $40 X$ magnification.

F) IHC score 4 at $40 \mathrm{X}$ magnification.
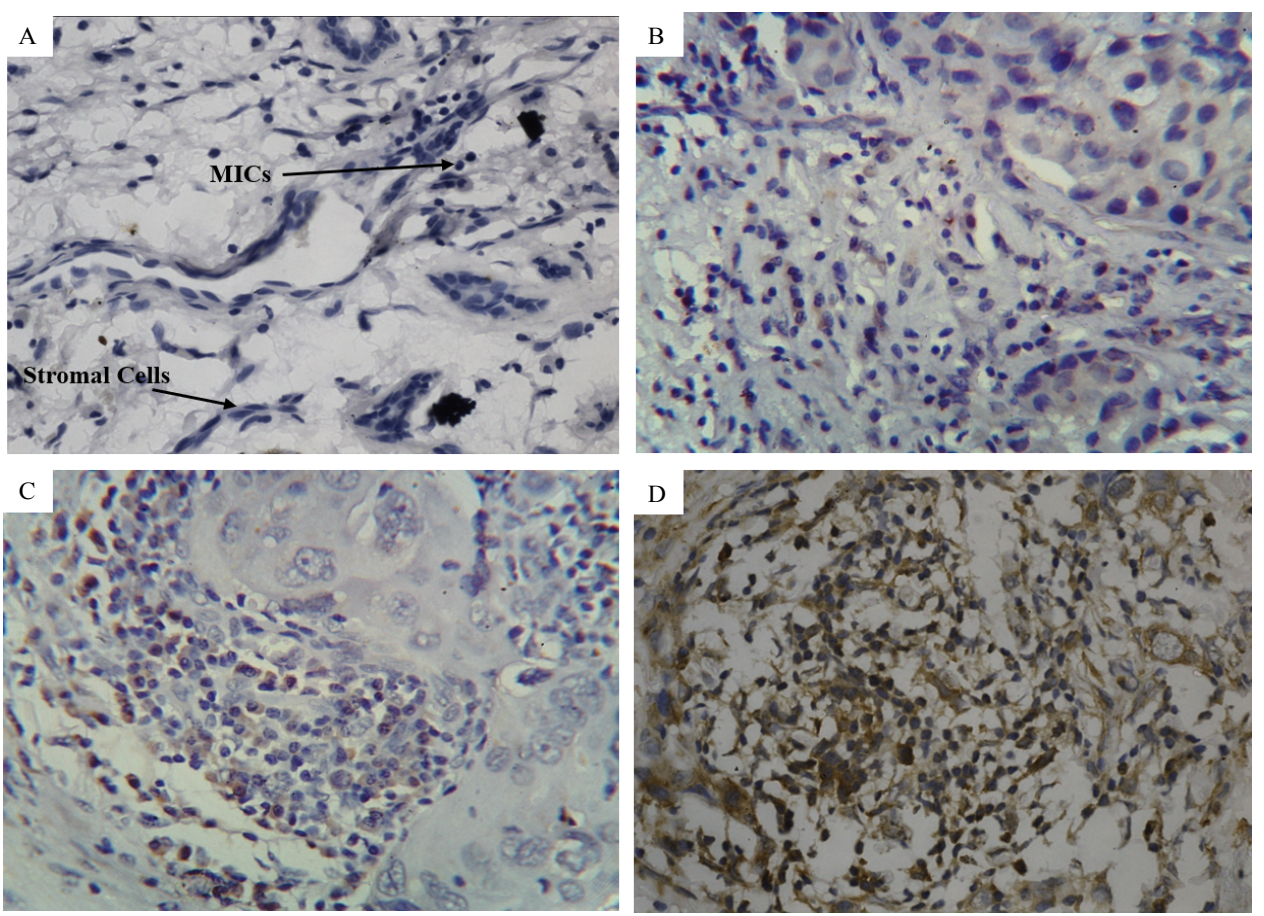

Figure 2: Immunohistochemical analysis for the expression of TLR9 in adjacent stromal cells of breast tumor tissue.

A) Experimental Negative Control 40X magnification; B to D: stained with TLR9 primary antibody.

B) IHC score 0 at $40 X$ magnification.

C) IHC score 1 at $40 X$ magnification.

D) IHC score 2 at 40X magnification. Arrows indicate the stromal cells with elongated plump spindle shaped nuclei and MIC with dark small round nuclei. 

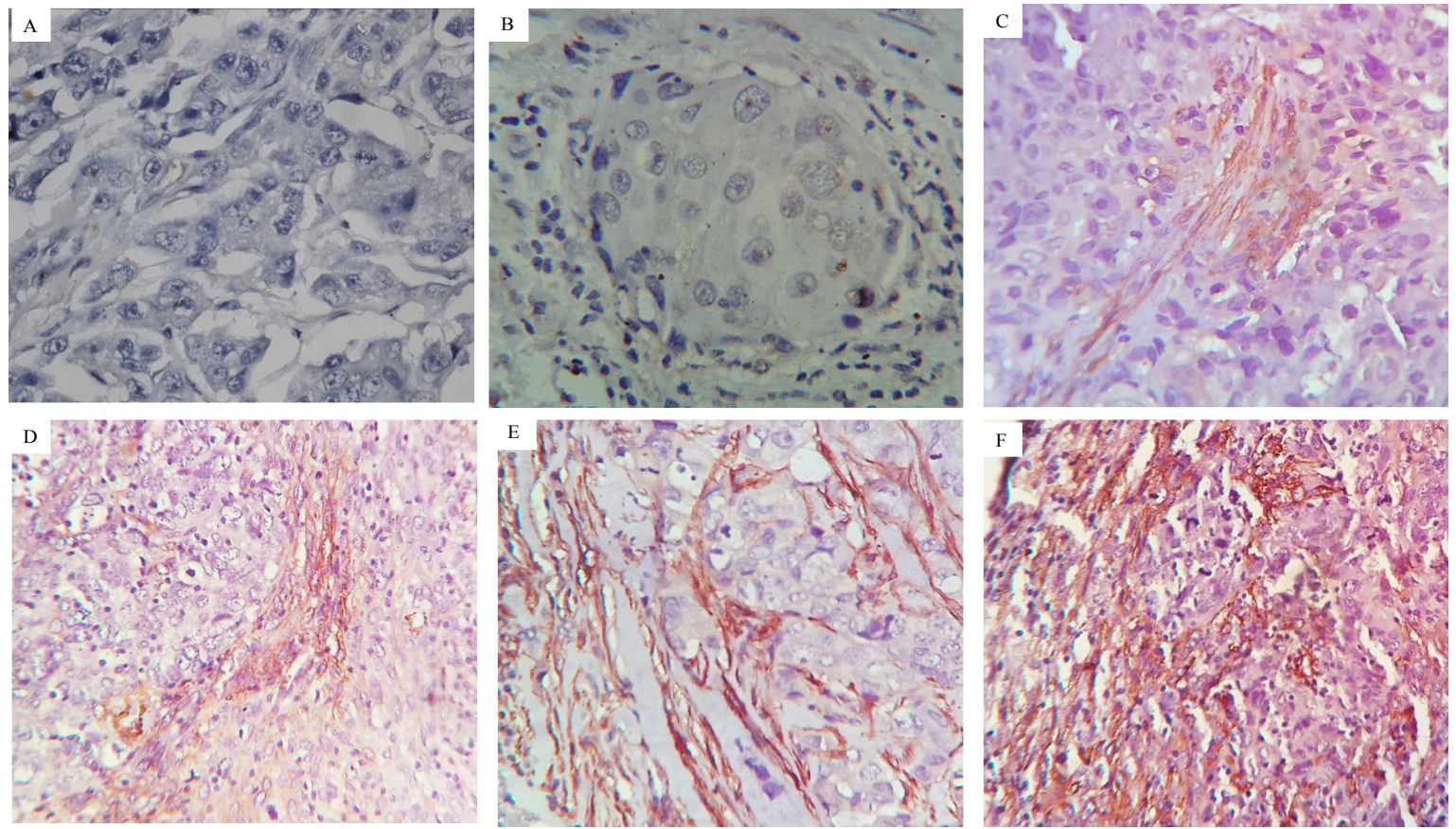

Figure 3: Immunohistochemical analysis of $\alpha$-SMA in adjacent stroma cells of breast tumor tissue.

A) Experimental Negative Control 40X magnification; B to F: stained with a-SMA primary antibody.

B) IHC score 0 at $40 \mathrm{X}$ magnification.

C) IHC score 1 at $40 X$ magnification.

D) IHC score 2 at $40 X$ magnification.

E) IHC score 3 at $40 X$ magnification.

F) IHC score 4 at $40 \mathrm{X}$ magnification.

Table 1: The association between TLR9 expression and clinical characteristics in breast cancer patients.

\begin{tabular}{|l|l|l|l|} 
& TLR9 & TLR9 & \\
Characteristics & Positive & Negative & p-value \\
& Score - 2-4 & Score 0-1 & \\
\hline
\end{tabular}

Malignant epithelial cells

\begin{tabular}{|c|c|c|c|}
\hline $\begin{array}{l}\text { Age } \\
\leq 50 \\
\geq 50\end{array}$ & $\begin{array}{l}11 \\
4\end{array}$ & $\begin{array}{l}16 \\
7\end{array}$ & $p>0.99$ \\
\hline $\begin{array}{l}\text { Histological grade } \\
\text { I } \\
\text { II } \\
\text { III }\end{array}$ & $\begin{array}{l}2 \\
10 \\
3\end{array}$ & $\begin{array}{l}4 \\
14 \\
5\end{array}$ & $p=0.86$ \\
\hline $\begin{array}{l}\text { Lymph node status } \\
\text {-ve } \\
\text { +ve }\end{array}$ & $\begin{array}{l}5 \\
10\end{array}$ & $\begin{array}{l}17 \\
6\end{array}$ & $p=0.02$ \\
\hline Adjacent stroma & & & \\
\hline $\begin{array}{l}\text { Age } \\
\leq 50 \\
\geq 50\end{array}$ & $\begin{array}{l}4 \\
1\end{array}$ & $\begin{array}{l}23 \\
10\end{array}$ & $p>0.99$ \\
\hline $\begin{array}{l}\text { Histological grade } \\
\text { I } \\
\text { II } \\
\text { III }\end{array}$ & $\begin{array}{l}1 \\
4 \\
0\end{array}$ & $\begin{array}{l}5 \\
20 \\
8\end{array}$ & $p=N S$ \\
\hline $\begin{array}{l}\text { Lymph node status } \\
\text {-ve } \\
\text { +ve }\end{array}$ & $\begin{array}{l}3 \\
2\end{array}$ & $\begin{array}{l}20 \\
13\end{array}$ & $p>0.99$ \\
\hline
\end{tabular}

\section{Expression of $\alpha$-SMA in the breast tumor sample}

IHC assay performed on tumor samples confirmed that alpha SMA protein localizes, particularly in adjacent stromal cells, which are mainly comprised of stromal myofibroblast. The expression of $\alpha$-SMA has been observed in malignant epithelial cells in some cases also (Figure 3). The clinicopathological analysis indicated that $\alpha$-SMA expression in stromal cells of breast cancer has a significant association with age but no correlation with histopathological stage and lymph node metastasis (Table 2).

\section{Correlation of expression of TLR9 in ductal com- partment and expression of $\alpha$-SMA in stromal cells}

Previously the expression of TLR9 in malignant epithelial cells had been studied extensively in all subtypes of breast cancer, and its relationship with several clinicopathological parameters has also been studied [8]. So, we have tried to establish the correlation of TLR9 expression in malignant epithelial cells with the expression of $\alpha$-SMA in stromal cells. Nevertheless, there was no significant correlation between the expression of TLR9 in malignant epithelial cells with the expression of $\alpha$-SMA in adjacent stroma (Table 3).

TLR9 expression in the stromal compartment was significantly associated with $\alpha$-SMA based on IHC 
Table 2: The association between $\alpha-S M A$ expression and clinical characteristics in breast cancer patients.

\begin{tabular}{|c|c|c|c|}
\hline Characteristics & $\begin{array}{l}\text { a-SMA } \\
\text { Positive } \\
\text { Score - 2-4 }\end{array}$ & $\begin{array}{l}\alpha-S M A \\
\text { Negative } \\
\text { Score 0-1 }\end{array}$ & p-value \\
\hline \multicolumn{4}{|l|}{ Stromal cells } \\
\hline $\begin{array}{l}\text { Age } \\
\leq 50 \\
\geq 50\end{array}$ & $\begin{array}{l}11 \\
9\end{array}$ & $\begin{array}{l}16 \\
2\end{array}$ & $p=0.0327$ \\
\hline $\begin{array}{l}\text { Histological } \\
\text { grade } \\
\text { I } \\
\text { II } \\
\text { III }\end{array}$ & $\begin{array}{l}2 \\
15 \\
4\end{array}$ & $\begin{array}{l}4 \\
8 \\
5\end{array}$ & $p=0.72$ \\
\hline $\begin{array}{l}\text { Lymph node } \\
\text { status } \\
\text {-ve } \\
\text { +ve }\end{array}$ & $\begin{array}{l}15 \\
8\end{array}$ & $\begin{array}{l}8 \\
7\end{array}$ & $p=0.5$ \\
\hline
\end{tabular}

Table 3: Correlation in expression of TLR9 in tumor epithelial cells of the patients with $\alpha-S M A$ expression in stromal cells.

\begin{tabular}{|c|c|c|c|}
\hline $\begin{array}{l}\alpha-S M A \text { in } \\
\text { stromal cells }\end{array}$ & $\begin{array}{l}\text { TLR9 } \\
\text { Negative } \\
\text { malignant } \\
\text { cells } \\
\text { Score } 0-1\end{array}$ & $\begin{array}{l}\text { TLR9 Positive } \\
\text { malignant } \\
\text { cells } \\
\text { Score - 2-4 }\end{array}$ & p-value \\
\hline Positive (2-4) & 13 & 8 & \multirow{2}{*}{$p>0.99$} \\
\hline Negative (0-1) & 10 & 7 & \\
\hline
\end{tabular}

Table 4: Correlation in expression of TLR9 and $\alpha-S M A$ expression in stromal cells.

\begin{tabular}{|l|l|l|l|}
\hline $\begin{array}{l}\boldsymbol{\alpha}-S M A \\
\text { stromal cells }\end{array}$ & $\begin{array}{l}\text { TLR9 Negative } \\
\text { Stromal cell } \\
\text { Score } \mathbf{0 - 1}\end{array}$ & $\begin{array}{l}\text { TLR9 Positive } \\
\text { Stromal cell } \\
\text { Score - } 2\end{array}$ & p-value \\
\hline Positive $(2-4)$ & 17 & 4 & $p=0.04$ \\
\hline Negative $(0-1)$ & 16 & 1 & \\
\hline
\end{tabular}

\section{analysis in breast tumor tissues}

Previously the prognostic significance of TLR9 expression in the stromal compartment of breast tumor had been reported [8]. Increased numbers of stromal myofibroblast had been associated with improved outcomes in several human tumors [11]. The high content of stromal myofibroblast and MICs was associated with a better outcome in TNBCs patients [10]. However, the effect was not studied on the expression of $\alpha$-SMA in breast cancer. To assess the effect of TLR9 on the expression of $\alpha$-SMA in the adjacent stroma and its prognostic effect, we compared the expression of TLR9 in patients with the expression of $\alpha$-SMA. We observed that an increase in the expression of TLR9 in the stromal compartment increases the expression of $\alpha$-SMA in the form of an increased frequency of stromal myofibroblasts $(p=0.04)$ (Table
4).

\section{Discussion}

TLR9 expression shows cancer-specific prognosis in various cancer [3]. The prognostic significance of TLR9 in cancers appears to be double-edged. In esophageal cancer, TLR9 expression in fibroblast is associated with a low rate of lymph node metastasis. In case of glioma, TLR9 expression increases with increase in histological grade $[7,12,13]$ while in renal cell carcinoma, mucoepidermoid salivary gland carcinoma, and pancreatic cancer, low TLR9 expression is associated with poor survival [3]. TLR9 is expressed in all clinically relevant subtypes of breast cancer $[8,14]$. In the present study, we have studied the expression of TLR9 and $\alpha$-SMA in the breast tumor sample and its correlation with several clinical parameters. We have also analyzed the significance of TLR9 on the expression of $\alpha$-SMA in breast carcinoma tissues. TLR9 has been expressed both in malignant epithelial cells as well as in adjacent stromal compartment. The dual localization of the TLR9 has been observed in endosomal as well as sub-membranous. We also observed that, in cases where strong TLR9 expression in stromal cells have desmoplastic stroma with high MIC infiltration. The TLR9 expression status of tumor-associated fibroblast-like cells has been shown to be of prognostic value in breast cancer [15]. TLR9 expression by fibroblast-like cells was significantly associated with a low rate of distant metastases. Although the biological significance of TLR9 expression by stromal fibroblast-like cells is currently unknown [15].

On the other hand, expression of $\alpha$-SMA has been studied as an indicator of myofibroblast $[9,16,17]$. The myofibroblast has been reported be expressed by a variety of cancer and is positively correlated with accelerated tumor growth. Myofibroblast secretes different kinds of insulin-like growth factor-2 (IGF-2), stroma cell-derived factor 1 (SDF-1/CXCL12) which stimulates breast cancer cell proliferation through the CXCR4 receptor [5].

In recent studies, several tumors show the significance of TLR9 in the expression of $\alpha$-SMA. In idiopathic interstitial pneumonia (IIP) pathogenesis, activation of cells with CpG-ODN induces the expression of $\alpha$-SMA [16]. In the case of murine hepatocellular sarcoma cancer model, TLR9 -/- mice show a reduced level of $\alpha$-SMA in comparison to wild type mice [18]. $\alpha$-SMA expression was considered to be a predictive factor for prognosis in the ovarian tumor [19]. $\alpha$-SMA expression and stromal density are prognostic markers in resected pancreatic cancer patients [20].

In this study, we have found a positive correlation between expression of TLR9 in the stromal cell with the expression of $\alpha$-SMA in the stromal compartment, which may indicate the role of TLR9 in the induction of stromal compartment to induce the expression of 
$\alpha$-SMA. The positive correlation of TLR9 expression with lymph node metastasis as well as expression of $\alpha$-SMA indicate its positive effect on cancer metastasis and cancer progression.

Taken together, our data indicate that the expression of TLR9 in stromal cells of breast tumor positively affect the expression of $\alpha$-SMA in stromal cells that might indicate the positive effect of TLR9 in myofibroblast differentiation of stromal compartment. It has been reported that myofibroblast differentiation of the stromal cells positively induces the metastasis of the tumor and hence may act as poor prognostic marker for the disease $[5,21]$.

\section{Conflict of Interest}

The authors have declared that no conflict of interest exists.

\section{Funding}

Fellowship of AS is provided by State-funded Fellowship program, West Bengal.

\section{Acknowledgments}

Authors acknowledge Principal, Burdwan Medical College, and Hospital for support to carry out this study. Authors also acknowledge Mr. Kartick Karmakar, Medical Technologists, department of pathology, Burdwan Medical College, and Hospital for his technical support in this study.

\section{References}

1. Akira S, Hemmi H (2003) Recognition of pathogen-associated molecular patterns by TLR family. Immunol Lett 85 : 85-95.

2. Melisi D, Frizziero M, Tamburrino A, Zanotto M, Carbone C et al. (2014) Toll-like receptor 9 agonists for cancer therapy. Biomedicines 2: 211-228.

3. Chandler MR, Keene KS, Tuomela JM, Forero-Torres A Desmond R, et al. (2017) Lower frequency of TLR9 variant associated with protection from breast cancer among African Americans. PLoS One 12: e183832.

4. Catteau, X, Simon P, Noël JC (2014) Myofibroblastic stromal reaction and lymph node status in invasive breast carcinoma: Possible role of the TGF- $\beta 1 / T G F-\beta R 1$ pathway. BMC Cancer 14: 499.

5. Surowiak P, Murawa D, Materna V, Maciejczyk A, Pudelko $\mathrm{M}$, et al. (2007) Occurence of stromal myofibroblasts in the invasive ductal breast cancer tissue is an unfavourable prognostic factor. Anticancer Res 27: 2917-2924.

6. Nielsen SH, Willumsen N, Leeming DJ, Daniels SJ, Brix S, et al. (2019) Serological assessment of activated fibroblasts by alpha-smooth muscle actin ( $\alpha-S M A)$ : A noninvasive biomarker of activated fibroblasts in lung disorders. Transl Oncol 12: 368-374.

7. Sheyhidin I, Nabi G, Hasim A, Zhang RP, Ainiwaer J, et al
(2011) Overexpression of TLR3, TLR4, TLR7 and TLR9 in esophageal squamous cell carcinoma. World J Gastroenterol 17: 3745-3751.

8. Sandholm J, Selander KS (2014) Toll-like receptor 9 in breast cancer. Front Immunol 5: 330.

9. Yamashita M, Ogawa T, Zhang X, Hanamura N, Kashikura $Y$, et al. (2012) Role of stromal myofibroblasts in invasive breast cancer: stromal expression of alpha-smooth muscle actin correlates with worse clinical outcome. Breast cancer 19: $170-176$

10. Meseure D, Vacher S, Alsibai KD, Trassard M, Nicolas A, et al. (2016) Biopathological significance of TLR9 expression in cancer cells and tumor microenvironment across invasive breast carcinomas subtypes. Cancer Microenviron 9: 107-118.

11. Tjomsland V, Niklasson L, Sandström P, Borch K, Druid $\mathrm{H}$, et al. (2011) The desmoplastic stroma plays an essential role in the accumulation and modulation of infiltrated immune cells in pancreatic adenocarcinoma. Clin Dev Immunol 2011.

12. Meng Y, Kujas M, Marie Y, Paris S, Thillet J, et al. (2008) Expression of TLR9 within human glioblastoma. J Neurooncol 88: 19-25.

13. Zhang Y, Wang Q, Ma A, Li Y, Li R, et al. (2014) Functional expression of TLR9 in esophageal cancer. Oncol Rep 31: 2298-2304.

14. Tuomela J, Sandholm J, Kaakinen M, Patel A, Kauppila JH, et al. (2013) DNA from dead cancer cells induces TLR9-mediated invasion and inflammation in living cancer cells. Breast Cancer Res Treat 142: 477-487.

15. González-Reyes S, Marín L, González L, González LO, del Casar JM, et al. (2010) Study of TLR3, TLR4 and TLR9 in breast carcinomas and their association with metastasis. BMC Cancer 10: 665.

16. Meneghin A, Choi ES, Evanoff HL, Kunkel SL, Martinez FJ, et al. (2008). TLR9 is expressed in idiopathic interstitial pneumonia and its activation promotes in vitro myofibroblast differentiation. Histochem Cell Biol 130: 979-992.

17. Rao KB, Malanthi N, Narashiman S, Rajan ST (2014) Evaluation of myofibroblasts by expression of alpha smooth muscle actin: A marker in fibrosis, dysplasia and carcinoma. J Clin Diagn Res 8: 14-17.

18. Gäbele E, Mühlbauer M, Dorn C, Weiss TS, Froh M, et al. (2008) Role of TLR9 in hepatic stellate cells and experimental liver fibrosis. Biochem Biophys Res Commun 376: 271-276.

19. Kobayashi $H$, Tsuruchi $N$, Sugihara K, Kaku T, Saito $T$, et al. (1993) Expression of $\alpha$-smooth muscle actin in benign or malignant ovarian tumors. Gynecol Oncol 48: 308-313.

20. Sinn M, Denkert C, Striefler JK, Pelzer U, Stieler JM, et al. (2014) a-Smooth muscle actin expression and desmoplastic stromal reaction in pancreatic cancer: Results from the CONKO-001 study. Br J Cancer 111: 1917-1923.

21. Anggorowati N, Kurniasari CR, Damayanti K, Cahyanti T, Widodo I, et al. (2017) Histochemical and immunohistochemical study of $\alpha-S M A$, collagen, and PCNA in epithelial ovarian neoplasm. Asian Pac J Cancer Prev 18: 667-671.

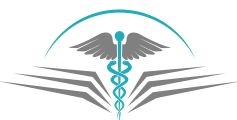

